\title{
Psychological Effect Of Bpjs Health Social Security participation In Perdagangan City Community
}

\author{
Andreas Purba \\ \{andreas.purbadasuha@gmail.com\} \\ Postgraduate of STT Pelita Kebenaran
}

\begin{abstract}
The Organizing Agency for Social Security(BPJS)is a service provided by the government to facilitate the lower economy community to obtain medical services. Therefore BPJS is a solution for overcoming the inability of communities to maintain their health. Indeed this somethingfor which every Indonesian citizen can be grateful.It is this matter that the researcher is interested in conducting research, in order to investigate to find out how the the society, in particular the Perdagangan City citizens who are participants of the BPJS Social Security Health program. Based on this, the question that arises is what is the number of participation of BPJS Social Security Health program in the Perdagangan City community? In order to answer this, the researcher collected dataand obtained the results, which show that the participation of BPJS was very high and was increasing every month.
\end{abstract}

Keywords: Psychological, Health social, BPJS,security participation

\section{Introduction}

The Organizing Agency for Social Securityor which is known in Indonesian is BPJS, is an institution of community servicethat helps alleviate burden for patients who are from low level economic background who incapable of paying for high medical costs, both in the community and in the hospital. The BPJS Social Security was introduced in 2014. By the BPJS program many people in society communities who previously would not be able to get medical help because of the high costs are assisted by the program. After seeing how bigthe benefits that can be obtained by the less able members of society both physically and economically, the researcher wanted to investigate whether people who are members of the BPJS Social Security in Perdaganagn City as locus have high interest in participating in the program. Furthermore, if the participation turns out to be high, what is the number? On the other hand if the participation is low, what is the number? This is the main objective of this research, i.e., to find out the condition in Perdagangan City with regards to BPJS Social Security participation.

\section{Theoretical review}

\subsection{BPJS Social Security}

BPJS was initially introduced as health insurance which then on 1 January 2014 was known as BadanPenyelenggaraJaminanSosial (Organizing Agency for Social Security) and better known in society as BPJS. If we consider the government organizational structure of the 
Organizing Agency for Social Security department, it can be seen that it is directly under the supervision of the Presidential Office as the head of state of Republic of Indonesia. Based on this it can be ascertained that the BPJS is a reliable program by the government in the interest of the welfare of people of the nation through the program.

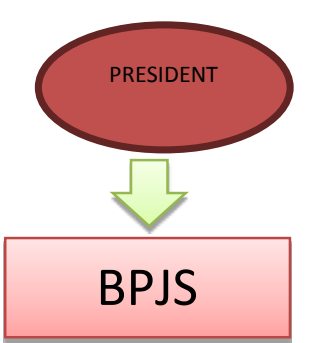

Fig. 1. BPJS in Government Structure

Based on the history of BPJS above, the social service program has been established since 1968, with the name and Organizer of the Health Care Fund (BPDPK). The table below shows BPJS's short history as administered by the government:

Tabel 1.Brief history of BPJS

\begin{tabular}{ll}
\hline Year & Different Names \\
\hline 1968 & BadanPenyelenggara Dana PemeliharaanKesehatan \\
1984 & Husada BhaktiPublic Company \\
1991 & $\begin{array}{l}\text { Program JaminanPemeliharaan under Husada } \\
\text { BhaktiPublic Company }\end{array}$ \\
1992 & Public Company became Corporation \\
2005 & $\begin{array}{l}\text { Penyelenggara Program Jaminan Kesehatan Masyarakat } \\
\text { Miskin } \\
2014\end{array}$ \\
& $\begin{array}{l}\text { BPJS Kesehatan } \\
\text { (Organizing Agency for Social Security) }\end{array}$ \\
\hline
\end{tabular}

The amount charged for each month for health BPJS users, for the month of September 2012 for individuals was Rp.22.000 per month and afterwards in March 2013 payments for each month was lowered based on particpants' income: Rp15.000 per month after obtaining subsidized natural gas from the government.

Table 2. Changes in BPJS monthly fee

\begin{tabular}{ll}
\hline September 2012 & Rp. 22,000 \\
\hline March 2013 & Rp. 15,500 \\
\hline
\end{tabular}

\subsection{Psychological Impact}

Behavior can be influenced by four things: genetics, attitudes, norms, as well as social, behavioral control. All four are very influential in the way individual thinks, including their actions. The way of thinking and viewing things is the factor that influences a person in his actions, because the problem that determines the actions of the individual is understanding and 
knowledge of the problem. In terms of knowledge, it depends on the decision of individuals in making conclusions after using his senses towards a particular object. Furthermore, there is attitude which is the response of individuals who are influenced by opinions and emotions in perceiving a particular object. Finally there are actions which are understood as something that arisesbased on individual familiarity, recognition and emotion. These three components give rise to decision to action and it is also relevant to the Perdagangan City community.

\section{Method}

The location of the research is Perdagagan City Health Center. This clinic was established in 1957 still present until now. With the duration of the establishment, the Health Center has gained the trust and confidence of the community, as can be seen from the long standing of this center, still being accepted by the community until the present time. Therefore the Trade Health Center is representative and feasible for research, to find out how the members of the community visit the center every month throughout 2018, from September to November. The method used in finding information will be the participation of the public BPJS in Perdangangan City, namely by collecting data regarding the number of visits in the community health center. The source of the data used was that the list of community participation and the number of visits each month.

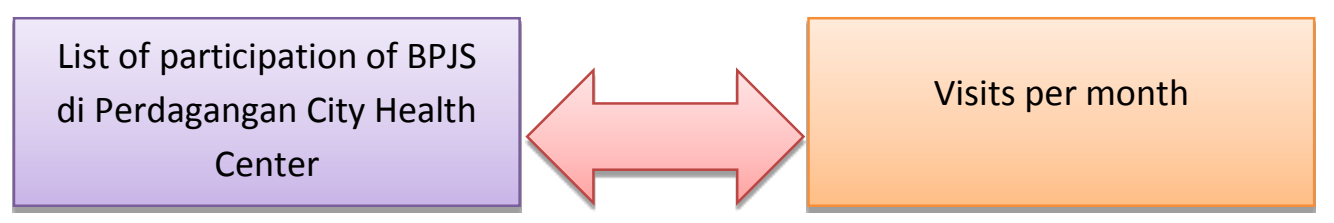

Fig . 2. Methods of data collection for number of participation and number of visits

\section{Results}

After collecting data at the research site at the Perdagangan City Health Center, based on the data, from the list of BPJS participants each monthwas found. The data collection starts from September 2018 to December 2018, wherein September 2018 the participation of BPJS reached 26,614 with a total visit of 5,583. Whereas in October 2018, the membership amounted to 26,984, with the number of visits totaling 5,685 times. In November 2018 the participation of BPJS amounted to 27,787, with the total number of visits of 5,611 times. Finally in December 2018 was the number of BPJS members was 27,942 with visits totaling 5,908 times. 


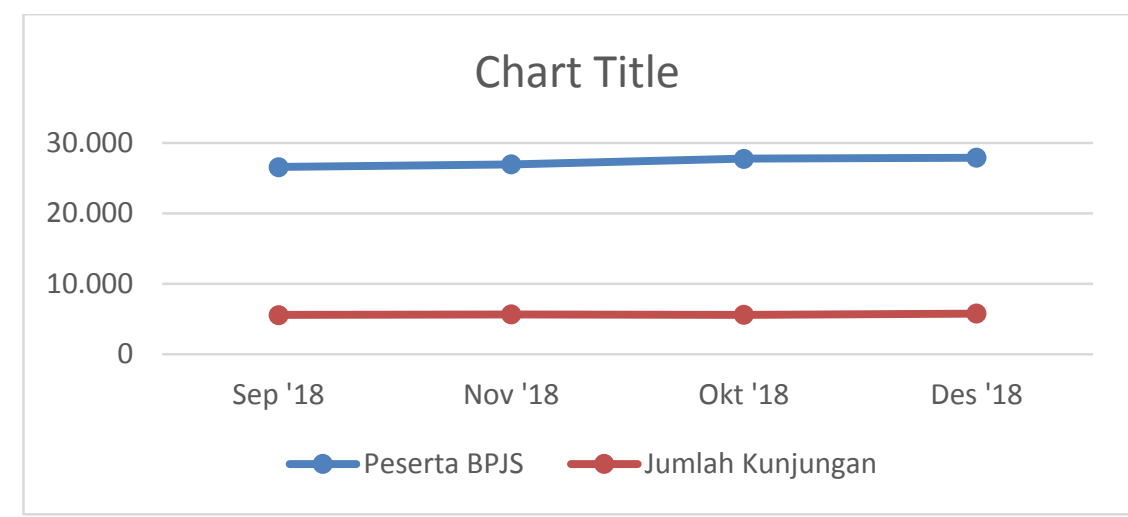

Figure 3. Comparative charts and participation of BPJS and number of visits at the Perdagangan City Health Center

From the above data, it can be seen that the number of BPJS participation is mostly in December 2018 with a total of 27,942 people. While the total number of visits to the December December 2018 totaled 5,808 times. The participation was lower in September 2018 with a total of 26,614 people and the lowest number of visits in September as many as 5,583 times increased on the total number of 5,685 times and decreased in November as many as 5,611 times and increased back to 5,808 times.

\section{Conclusion}

In accordance with the question of regarding the number of interests from the community of Perdagangan City in the BPJS, after investigating the data, it was found that it is increasing from September to December. Thus it is known that the Community in Perdagangan City has a high level of trust and awareness of the increasing BPJS in their lives.

The conclusion that can be drawn is that the people of Perdagangan City posses a high level of awareness and understanding concerning BPJS Social Security. The results also relect that the people are helath conscious without having to pay costs for medical service.

The suggestion that can be given based on this research is that the people of Perdagangan City should further promote the importance of BPJS social security, namely that it is a solution to obtain medical service and maintain health and that the public should trusts the BPJS Social Security Program that enable people to gat medical treatment without paying a high cost.

\section{Reference}

[1]Wikipedia (2015). BPJS Kesehatan. DikutipFebruari, 27, 2019, dari [2]https://id.wikipedia.org/wiki/BPJS_Kesehatan

[3] kbr (2012). KemenkokesraPesimistisSubsidiIuran BPJS KesehatanCukupBuat 86 juta Rakyat Miskin. DikutipFebruari, 27, 2019, dari https://kbr.id/NASIONAL/02-

2013/kemenkokesra_pesimistis_subsidi_iuran_bpjs_kesehatan_cukup_buat_86_juta_rakya t_miskin/20070.html 
[4] Kbr (2013). Kemenkeu: Negara HanyaMampuSubsidiIuran BPJS Rp 15 Ribu Per Bulan. DikutipFebruari, 27,2019,

darihttps://kbr.id/NASIONAL/022013/kemenkeu_negara_hanya_mampu_subsidi_iuran_ bpjs_rp_15_ribu_per_bulan/20066.html

[5] Wikipedia (2019). BadanPenyelenggaraJaminanSosial. DikutipFebruari, 27, 2019, dari https://id.wikipedia.org/wiki/Badan_Penyelenggara_Jaminan_Sosial\#cite_note-7

[6] Albarracín, Dolores, Blair T. Johnson, \& Mark P. Zanna. The Handbook of Attitude. Routledge, 2005. Hlm. 74-78

[7] LaporanbulananPuskesmasPerdagangan, diambil 12 Februari 2019. 